\title{
The Electoral College's Impact on Presidential Campaigns
}

\author{
Yusuf Khan \\ Department of Political Science \\ University of Nebraska - Omaha \\ Arts \& Sciences Hall 280, 6001 Dodge Street Omaha, NE \\ The United States of America
}

\begin{abstract}
An analysis of the relationship between the electoral college and its impact on presidential candidates' attention or visits to each state. The study seeks to understand and answer the question of how the electoral college impacts the attention of presidential candidates to each state. The analysis found that certain states defined within the study as "battleground" or "toss up" states are much more likely to be visited by presidential candidates, and, in addition, the data showed that there is a hierarchy within battleground states. The states that have a higher number of electoral votes were visited more often than other smaller electoral vote tossup states. This shows there is a direct correlation between a state being deemed a "battleground" state, thus having more electoral votes to the attention or visits a presidential candidate shows to that state.
\end{abstract}

Keywords: Battleground, Toss up, Electoral college, Votes, Presidential, Democrat, Republican

\section{Introduction}

The Electoral College has been a fair source of frustration in the eyes of the common voter for the past few decades, regardless of voter affiliation to either political party. Democrats were furious in 2000, when Vice President Al Gore lost his election campaign for the Presidency because he lost the electoral college, while winning the popular vote. Likewise, Republicans have voiced complaints about the electoral college providing Democrats multiple ways to victory, while pigeonholing Republican candidates in securing victory solely by winning a number of battleground states. Many concerns have been raised by citizens, the media, and even a number of politicians as to what impact the Electoral College has on the attention that presidential candidates lavish on the states that are toss up states. The purpose of this investigation is to focus and examine the relationship between the number of Electoral College votes each state has and compare them to the number of visits by presidential candidates to each state. Prior research has focused on whether the Electoral College should be changed or removed or what party it helps, rather than the impact of it on presidential campaigns. This research will contribute a new area of study regarding the Electoral College's impact on presidential campaigns.

\section{Literature Review}

The body of quantitative research on impacts of the Electoral College teems with variables, exploratory research, and dedicated interest in the topic. The majority of the articles researched had many different stances on the Electoral College, and whether it should be abolished or not, but one commonality that existed was that candidates were extremely affected by the system of the electoral college, which plays a major part in their campaign operations (Wright, 2008).

Electoral College research is frequently marred by political bias in the form of one of the two major parties, and turns into a "he said, she said" debate. In the aftermath of an election a party will celebrate the history of the college and impress upon others the importance of the practice. Four years later those same people can often be found doing the exact opposite (Collin, 2016). A key example of this would be how much Republicans complained about the electoral college in the lead up to the 2016 election, but immediately after winning due to three key battleground states the parties switched views on the electoral college ( Flegenheimer, Matt, \& Barbaro, 2016). They bemoaned the lack of "democracy" in the country and insisted that the Electoral College must be repealed (Fon, 2004). Everyone will agree that the Electoral College does favor battleground states no matter their stance on the system (Kedar, Harsgor, \& Sheinerman, 2015). In addition, there is the question over whether battleground states are truly most valued, or battleground states with a large electoral college vote (Brawner, 2016). There has been a long debate on whether large states or small states derive the most power or hold any advantage through the electoral college, but John Wright brings up the possibility that the true power lies in the hands of states that are considered "competitive" or "toss up" (Wright, 2008). 
This in essence is the hard, factual based evidence that most citizens and voters don't really consider, but really should. States that are either a deep red state like Nebraska, or a deep blue state like California get very little consideration from major party presidential candidates in the general election (Riggs, Hobbs, \& Riggs, 2009).

Why would a Republican presidential candidate bother campaigning in California? Why would a Democrat candidate bother campaigning in Missouri? Instead candidates focus and visit key states such as Florida, Ohio, Pennsylvania, North Carolina, and Virginia, to name a few (Grofman \& Feld, 2005) The question that really needs to be discussed is how much of an impact this campaign practice has on politicians campaigns?

\section{Bivariate Directional Hypothesis}

In short, politicians frequent and spend more time and money in states that are considered "toss up", and this relates directly to the Electoral College "winner-take-all" system. Thus, our hypothesis is that the Electoral College votes a state has is a direct representation of the average number of visits that a presidential candidate undertakes to a state during the election cycle barring exceptions in stronghold or safe states.

\section{Methodology}

The Independent Variable (IV) in the research is the number of electoral votes that each state has. The Dependent Variable (DV) is the average number of visits that a presidential candidate undertakes to a state during the election cycle. Within the study there is the caveat that presidential candidates are way more likely to visit battleground states rather than states that are considered safe or stronghold states. Keeping this in mind, looking at all 50 states is a good way to examine this hypothesis. The sample size are the 50 states and the time period is over the past 3 presidential election cycles. That contains the elections of 2016, 2012, and 2008. There were 3 tables created (one for each presidential election year) that includes all 50 states in one column, not differentiating between the states considered battleground or safe states, the number of electoral college votes each state had during each presidential cycle, and the number of visits by both major party candidates. A state was classified as safe or battleground by the pre collected data from the New York Times (NYT) for each election cycle. The 2008 table is shown in Table 1:

Table 1: The 2008 election showing each state with the number of electoral votes it has along with the total number of visits that were made to the state by presidential candidates

\begin{tabular}{|l|l|l|l|}
\hline 2008 & Category & Electoral Votes & Visits \\
\hline State (Name) & Safe-Red & 9 & 0 \\
\hline Alabama & Safe-Red & 3 & 0 \\
\hline Alaska & Safe-Red & 10 & 2 \\
\hline Arizona & Safe-Red & 6 & 0 \\
\hline Arkansas & Safe-Blue & 55 & 0 \\
\hline California & Lean Blue & 9 & 17 \\
\hline Colorado & Safe-Blue & 7 & 0 \\
\hline Connecticut & Safe-Blue & 3 & 0 \\
\hline Delaware & Tossup & 27 & 30 \\
\hline Florida & Lean Red & 15 & 0 \\
\hline Georgia & Safe-Blue & 4 & 0 \\
\hline Hawaii & Safe-Red & 4 & 0 \\
\hline Idaho & Safe-Blue & 21 & 1 \\
\hline Illinois & Tossup & 11 & 10 \\
\hline Indiana & Lean Blue & 7 & 8 \\
\hline Iowa & Safe-Red & 6 & 0 \\
\hline Kansas & Safe-Red & 8 & 0 \\
\hline Kentucky & Safe-Red & 9 & 0 \\
\hline Louisiana & Safe-Blue & 4 & 1 \\
\hline Maine & Safe-Blue & 10 & 1 \\
\hline Maryland & Safe-Blue & 12 & 0 \\
\hline Massachusetts & Safe-Blue & 17 & 12 \\
\hline Michigan & Lean Blue & 10 & 1 \\
\hline Minnesota & Safe-Red & 6 & 0 \\
\hline Mississippi & Tossup & 11 & 16 \\
\hline Missouri & Lean Red & 3 & 0 \\
\hline Montana & & & \\
\hline
\end{tabular}




\begin{tabular}{|l|l|l|l|}
\hline Nebraska & Safe-Red & 5 & 0 \\
\hline Nevada & Lean Blue & 5 & 9 \\
\hline New Hampshire & Lean Blue & 4 & 9 \\
\hline New Jersey & Safe-Blue & 15 & 0 \\
\hline New Mexico & Lean Blue & 5 & 9 \\
\hline New York & Safe-Blue & 31 & 10 \\
\hline North Carolina & Tossup & 15 & 13 \\
\hline North Dakota & Lean Red & 3 & 0 \\
\hline Ohio & Tossup & 20 & 35 \\
\hline Oklahoma & Safe-Red & 7 & 0 \\
\hline Oregon & Safe-Blue & 7 & 0 \\
\hline Pennsylvania & Lean Blue & 21 & 29 \\
\hline Rhode Island & Safe-Blue & 4 & 0 \\
\hline South Carolina & Safe-Red & 8 & 0 \\
\hline South Dakota & Safe-Red & 3 & 0 \\
\hline Tennessee & Safe-Red & 11 & 1 \\
\hline Texas & Safe-Red & 34 & 1 \\
\hline Utah & Safe-Red & 5 & 0 \\
\hline Vermont & Safe-Blue & 3 & 0 \\
\hline Virginia & Lean Blue & 13 & 21 \\
\hline Washington & Safe-Blue & 11 & 0 \\
\hline West Virginia & Lean Red & 5 & 1 \\
\hline Wisconsin & Lean Blue & 10 & 11 \\
\hline Wyoming & Safe-Red & 3 & 0 \\
\hline
\end{tabular}

After all the data was collected it was analyzed by first specifying whether the hypothesis at the beginning of the study was true. If over $90 \%$ of the "safe" states were not visited over 5 times in total by the presidential candidates in all of the election cycle years for which data was available, it can be concluded that the hypothesis was correct and most (if not all) presidential candidates focus on battleground states in terms of visitation. After this the data collected for the battleground states was surveyed and then an equation that correlated the number of Electoral College votes to the number of visits by presidential candidates over the election cycle was formulated. If it was found that battleground states with a small number of electoral college votes were visited as often as battleground states with a high number of electoral college votes than it can be concluded that the hypothesis was proven wrong. However, if it seems that there is a correlation meaning that a significant number of visits to battleground states with higher electoral college votes were made, rather than battleground states with a low number of electoral college votes, then it can be concluded that the hypothesis was correct and the data can be further examined to see what other factors may affect it.

\section{Analysis}

After gathering the data for the three election cycles, it was very clear that on average battleground or toss up states are visited more often by presidential candidates. In the three election cycles that data was gathered for the two major party candidates would often overlook visiting most of the 50 states except for the 10-15 toss up or lean red/lean blue states.

\subsection{Election}

In 2008 the NYT identified 5 toss up states which were Florida, Indiana, Missouri, North Carolina, and Ohio. Of those 5 states considered toss ups, they all had a relatively high number of electoral votes each, as shown in Table 2 . Within this sample of data, it can be seen that generally as the number of electoral votes increased for each state, the number of visits did as well, therefore being an inclination of proof to support the hypothesis of this paper.

Table 2: In 2008 the NYT identified 5 toss up states, as seen below, along with the number of electoral votes each state had and the total number of visits made by presidential candidates

\begin{tabular}{|l|l|l|l|}
\hline 2008 & Category & Electoral Votes & Visits \\
\hline State (Name) & Toss Up & 27 & 30 \\
\hline Florida & Toss Up & 11 & 10 \\
\hline Indiana & Toss Up & 11 & 16 \\
\hline Missouri & Toss Up & 15 & 20 \\
\hline North Carolina & Toss Up & 20 & 35 \\
\hline Ohio & & & 35 \\
\hline
\end{tabular}




\subsection{Election}

In 2012, the NYT identified 6 toss up states which were Colorado, Florida, Iowa, North Carolina, Ohio, and Virginia, as shown in Table 3. Much like in 2008, as the number of electoral votes increased for each state so did the number of visits the presidential candidates undertook to those toss up states. One notable exception to this was North Carolina where there were only 5 visits, but this did not take into account that the Democratic National Convention was held in Charlotte, North Carolina that year.

Table 3: The 6 toss up states identified by the NYT for the 2012 election with the number of electoral votes it has along with the total number of visits that were made to the state by presidential candidates

\begin{tabular}{|l|l|l|l|}
\hline 2012 & Category & Electoral Votes & Visits \\
\hline State (Name) & Toss Up & 9 & 24 \\
\hline Colorado & Toss Up & 29 & 58 \\
\hline Florida & Toss Up & 6 & 27 \\
\hline Iowa & Toss Up & 15 & 5 \\
\hline North Carolina & Toss Up & 18 & 73 \\
\hline Ohio & Toss Up & 13 & 45 \\
\hline Virginia & \multicolumn{2}{|l}{} \\
\hline
\end{tabular}

\subsection{Election}

In 2016, there were 7 battleground states which included Colorado, Florida, Iowa, Michigan, North Carolina, Ohio, and Pennsylvania as shown in Table 4.

Table 4: In 2016, there were 7 battleground states identified by NYT, as seen in the table below, along with the electoral votes allotted to each state and the total number of visits made by presidential candidates to that state for that election cycle.

\begin{tabular}{|l|l|l|l|}
\hline 2016 & Category & Electoral Votes & Visits \\
\hline State (Name) & Toss Up & 9 & 19 \\
\hline Colorado & Toss Up & 29 & 71 \\
\hline Florida & Toss Up & 6 & 21 \\
\hline Iowa & Toss Up & 16 & 22 \\
\hline Michigan & Toss Up & 15 & 55 \\
\hline North Carolina & Toss Up & 18 & 48 \\
\hline Ohio & Toss Up & 20 & 54 \\
\hline Pennsylvania & &
\end{tabular}

The data once again shows that in general the amount of visits to a state increases as the number of electoral votes for that state increase. Again, we have the notable exception of North Carolina disrupting the trend, but this may also be a factor due to the limited attention North Carolina was given in previous election cycles since before 2008 it was a solid Republican safe state. The increased attention in 2016 was also a result of both campaigns believing that any victory hinged on them winning North Carolina, explaining the uncharacteristically high number of visits by both Donald Trump and Hillary Clinton.

\section{Conclusion}

The hypothesis states that "in short, politicians frequent and spend more in states that are considered "toss up", and this relates directly to the electoral college "winner-take-all" system. Thus, we hypothesize that the electoral college votes a state has is a direct representation of the average number of visits that a presidential candidate undertakes within a state during the election cycle barring exceptions in stronghold or safe states" was generally supported by the data collected in this study, with one notable exception being North Carolina, while the rest of the toss up states generally followed the trend. In the future it would be prudent to look at implementing more variables into this research and expanding on the current research, adding on factors like historical precedent, money spent in each toss up state, etc.

\section{Acknowledgements}

We acknowledge the efforts of Dr. Travis King, Dr. Gul Ahmad and Aatiya Ahmad for their immense help in proofreading and editing this paper. 


\section{References}

Brawner, Steve. 2016. "Brawner: Every County Is Purple.” Times Record

http://www.swtimes.com/opinion/20161120/brawner-every-county-is-purple (December12, 2018).

Collin, Katy. 2016. "The Electoral College Badly Distorts the Vote. And It's Going to Get Worse." The Washington Post.https://www.washingtonpost.com/news/monkey-cage/wp/2016/11/17/the-electoral-college-badly-distortsthe-vote-and-its-going-to-get-worse/?utm_term=.74e136bbc4ba(December 12, 2018).

Flegenheimer, Matt, and Michael Barbaro. 2016. "Donald Trump Is Elected President inStunning Repudiation of the Establishment." The New York Times.https://www.nytimes.com/2016/11/09/us/politics/hillary-clinton-donaldtrump-presidenthtml (December 12, 2018).

Fon, Vincy. 2004. "Electoral College Alternatives and U.S. Presidential Elections." SSRNElectronic Journal, 41-73.

Grofman, Bernard, and Scott L. Feld. 2005. "Thinking About the Political Impacts of theElectoral College." Public Choice 123(1-2): 1-18.

Kedar, Orit, Liran Harsgor, and Raz A. Sheinerman. 2015. "Are Voters Equal under Proportional Representation?" American Journal of Political Science 60(3): 676-91.

Riggs, Jack E., Gerald R. Hobbs, and Todd H. Riggs. 2009. "Electoral College Winners Advantage." PS: Political Science \& Politics 42(02): 353-57.

Wright, John R. 2008. "Pivotal States in the Electoral College, 1880 to 2004." Public Choice, 139 (1-2): 21-37. 